\title{
Antidiarrheal activity of aqueous ethanol extract of Cyperus esculentus tuber in albino rats
}

\author{
Olusayo A. Shorinwa*, Deborah T. Dambani \\ Department of Experimental Pharmacology and Toxicology, Faculty of Pharmaceutical Sciences, University of Port Harcourt, Port Harcourt, Nigeria.
}

\section{ARTICLE INFO \\ Article history: \\ Received on: April 13, 2019 \\ Accepted on: March 30, 2020 \\ Available online: May 26, 2020}

\section{Key words:}

Antidiarrheal, castor oil, charcoal

meal, Cyperus esculentus, ethanol

\begin{abstract}
Cyperus esculentus is used in the treatment of diarrhea in traditional medicine. Antidiarrheal activity of aqueous ethanol extract of $C$. esculentus tuber was investigated in albino rats with castor oil induced and charcoal meal assays. Acute toxicity and preliminary phytochemical constituents were determined. Fifty albino rats were divided into five groups of five animals each for each assay. The extract was administered at doses of 250, 500, and 1,000 $\mathrm{mg} / \mathrm{kg}$, loperamide at $2 \mathrm{mg} / \mathrm{kg}$, and atropine at $0.1 \mathrm{mg} / \mathrm{kg}$ (positive control groups), while $1 \%$ tracaganth mucilage was given to negative control group. The LD50 was above $5,000 \mathrm{mg} / \mathrm{kg}$. Phytochemical evaluation indicated the presence of steroids, carbohydrates, alkaloids, and saponins. A non-statistically significant $(p>0.05)$ decrease in mean weight of wet feces $(1.71 \pm 1.23 \mathrm{~g}, 1.75 \pm 0.77 \mathrm{~g})$ and mean frequency of watery defecation $(1.6 \pm 1.03$, $1.8 \pm 0.97)$ at 500 and $1,000 \mathrm{mg} / \mathrm{kg}$ extract doses. Percentage inhibition of defecation was $46.7 \%$ and $40 \%$ at 500 and $1,000 \mathrm{mg} / \mathrm{kg}$ doses of the extract, respectively, while that of loperamide was $46.7 \%$ relative to the negative control in castor oil induced test. The findings have shown that the aqueous ethanol extract of $C$. esculentus tuber seems to possess anti-secretory effect but does not have anti-motility effect.
\end{abstract}

\section{INTRODUCTION}

Diarrhea is the passage of three or more loose or liquid stools per day, or more frequent passage than is normal for an individual occurring when various factors interfere with the normal intestinal physiology, resulting in decreased absorption, increased secretion of fluid and electrolytes, or increased bowel motility. The most severe threat posed by diarrhea is dehydration [1] occurring when the losses in fluid and electrolytes are not replaced.Plants have long been a very important source of new drugs in the management of several conditions, including diarrhea with approximately $25 \%$ of drugs derived from them [2]. In many parts of Africa, medicinal plants are the most easily accessible health resource available to the community [3]. Traditionally, people consider them efficacious against disorders without a scientific basis [3]. In addition, they are most often preferred option for the patients [3] as antidiarrheal medications in contemporary medicine may present

\footnotetext{
*Corresponding Author

Olusayo A. Shorinwa, Department of Experimental Pharmacology and Toxicology, Faculty of Pharmaceutical Sciences, University of Port Harcourt, Port Harcourt, Nigeria.

E-mail: Olusayo.shorinwa@uniport.edu.ng sayoshorinwa@yahoo.com
}

with adverse effects and microbial resistance tends to develop in the use of antibiotics. Cyperus esculentus (Tiger nut) is an annual or perennial plant, a species of sedge, native to warm temperate to subtropical regions of the Northern Hemisphere, belonging to the family Cyperaceae [4]. It is cultivated in Western Africa [4] and popularly consumed by humans. It possesses several medicinal properties, such as anti-inflammatory [5], hepatoprotective [6], antioxidant [7], antibacterial [5], antifungal [5], and anticonvulsant [5]. In Ayurvedic medicine, it is used in the treatment of flatulence, indigestion, colic, diarrhea, dysentery, debility, and excessive thirst [8]. There has been no previous scientific evaluation of its antidiarrheal activity. Hence, this study aims to investigate the antidiarrheal activity of $C$. esculentus tuber.

\section{MATERIALS AND METHODS}

\subsection{Collection of the Plant Materials}

The dried tubers of C. esculentus (Tiger nut) were purchased from Sangana market, Diobu in Port Harcourt city, Rivers State and were authenticated by Dr. Ekeke Chimezie of the Department of Plant Science and Biotechnology, University of Port Harcourt. A voucher specimen assigned with $\mathrm{UPH} / \mathrm{C} / 103$ was deposited in the herbarium of the above named department. 


\subsection{Plant Extract Preparation}

The dried tubers were cleaned and pulverized using a mechanical grinder. The powdered tuber $(3.83 \mathrm{~kg})$ of $C$. esculentus was subjected to solvent extraction for 72 hours with 9.21 of $50 \%$ ethanol. The extract was concentrated using a rotary evaporator, carefully evaporated to dryness over a water bath at $45^{\circ} \mathrm{C}$ and then placed in a desiccator using silica gel. The percentage yield was determined and the dried extract was stored in a refrigerator.

\subsection{Animals Used}

Sixty-eight albino rats with average weight of $195 \mathrm{~g}$ were made use of in this study. They were kept in plastic cages with wire mesh under normal room temperature in the Department of Experimental Pharmacology and Toxicology laboratory and provided with food and water ad libitum.

\subsection{Drugs and Chemicals Used}

Absolute ethanol, Diethyl ether (JHD Guangdong Guanghua SciTech.Co. Ltd. Shantou, Guangdong, China); Castor oil B.P. (Bell, Sons \& Co Druggists Limited, United Kingdom); Loperamide tablet, $2 \mathrm{mg}$ (Imodium, Janssen Pharmaceuticals, Belgium); Atropine sulfate injection USP $0.6 \mathrm{mg} / \mathrm{ml}$; Tragacanth gum; Activated charcoal.

\subsection{Qualitative Phytochemical Analysis}

Phytochemical analysis was done according to established protocols as described by Harborne [9].

\subsection{Acute Toxicity Study}

Acute toxicity of the tuber of $C$. esculentus was determined using 18 albino rats. The rats were divided into six groups of three animals each. The first three groups were treated with extract doses of 10, 100, and 1,000 $\mathrm{mg} / \mathrm{kg}$ aqueous ethanol extract of $C$. esculentus respectively. The animals were under observation for 24 hours for signs of mortality or morbidity or death. The animals showed no sign of adverse effects after the period of observation. Doses of $1,600,2,900$, and $5,000 \mathrm{mg} / \mathrm{kg}$ were then administered to the remaining three groups and kept under observation for another 24 hours [10].

\subsection{Castor Oil-Induced Diarrhea}

Twenty-five rats were used in this experiment which did not have access to feed for 18 hours. They were randomized into five groups of five animals each. Group A animals were administered with $0.1 \mathrm{ml}$ of aqueous $1 \%$ tragacanth suspension, group $\mathrm{B}$ animals received loperamide ( $2 \mathrm{mg} / \mathrm{kg}$ ), while groups $\mathrm{C}, \mathrm{D}$, and E were given the three test doses $(250,500$, and $1,000 \mathrm{mg} / \mathrm{kg})$ of the extract, respectively, through the oral route with the aid of a cannula. Each animal was then treated with $1 \mathrm{ml}$ of castor oil orally after a period of 1 hour.

After 1 hour, all groups received $1 \mathrm{ml}$ of castor oil each orally. The animals were then placed in cages lined with Whatmann filter papers and observed for characteristic diarrheal droppings for 4 hours.
The number of defecation, weight of paper before and after defecation were noted [11]. The activity was expressed as $\%$ inhibition of defecation.

$\%$ inhibition of defecation $=[(A-B) / A] \times 100$

$A=$ Mean number of watery diarrhea of negative control.

$B=$ Mean number of watery diarrhea of drug/ extract.

\subsection{Charcoal Meal Test}

Twenty-five albino rats that did not have access to feed for 18 hours prior to the experiment were used. The animals were allotted into groups of five animals per group. The control group received $0.1 \mathrm{ml}$ aqueous $1 \%$ tragacanth suspension while the second group was administered with $0.1 \mathrm{mg} / \mathrm{kg}$ atropine (reference drug) intraperitoneally. Animals in groups C, D, and E were orally administered 250,500 , and $1,000 \mathrm{mg} / \mathrm{kg}$ of the extract, respectively. Each group was later given $1 \mathrm{ml}$ of $10 \%$ activated charcoal suspended in $10 \%$ aqueous tragacanth powder through the oral route, 30 minutes after the treatment. Animals were euthanized 30 minutes after charcoal meal administration by diethyl ether anesthesia. The abdomen was incised, and the small intestine carefully removed. The distance travelled by the charcoal plug from pylorus to caecum and the total length of the intestine was then measured [11]. The percentage transit and percentage of inhibition were calculated by using the following formula:

Percentage transit $=\frac{\text { Distance travelled by charcoal meal }}{\text { Total length of intestine }} \times 100$

Percentage intestinal inhibition $=\left(T_{0}-T_{\mathrm{I}} / T_{0}\right) \times 100$

$T_{0}=$ Mean total length of intestine

$T_{1}=$ Mean distance travelled by charcoal in intestine.

\subsection{Statistical Analysis}

The results are presented as mean \pm standard error of mean (SEM). The one-way analysis of variance test with Dunnett's post hoc test was used to analyze and compare the data using IBM SPSS version 21 software, while $p<0.05-0.001$ was taken as statistically significant.

\section{RESULTS}

\subsection{Preliminary Qualitative Phytochemical Analysis}

Preliminary qualitative phytochemical evaluation of the aqueous ethanol extract of C. esculentus showed the presence of alkaloids, steroids, cardiac glycosides, carbohydrate, and saponins. However, flavonoids, tannins, anthraquinones, and phlobatannins were observed to be absent in this extract.

\subsection{Acute Toxicity Study}

The result of oral acute toxicity studies showed that the $\mathrm{LD}_{50}$ of the aqueous ethanol extract of $C$. esculentus tuber was above 5,000 $\mathrm{mg} / \mathrm{kg}$ body weight. However, itching was observed at $1,000 \mathrm{mg} /$ $\mathrm{kg}$, sedation at $2,900 \mathrm{mg} / \mathrm{kg}$ and $5,000 \mathrm{mg} / \mathrm{kg}$, and piloerection (standing fur) at $5,000 \mathrm{mg} / \mathrm{kg}$. 
Table 1. Effect of aqueous ethanol extract of C. esculentus tuber on castor oil induced diarrhea (Mean $\pm \mathrm{SEM})$.

\begin{tabular}{lcccc}
\multicolumn{1}{c}{ Treatment } & Dose $(\mathbf{m g} / \mathbf{k g})$ & $\begin{array}{c}\text { Mean weight of } \\
\text { wet feces }(\mathbf{g})\end{array}$ & $\begin{array}{c}\text { Mean no. of } \\
\text { watery diarrhea }\end{array}$ & $\begin{array}{c}\text { Inhibition of } \\
\text { defecation }(\%)\end{array}$ \\
\hline $1 \%$ tragacanth & $1 \mathrm{ml}$ & $2.07 \pm 0.39$ & $3 \pm 0.91$ & 0 \\
Loperamide & 2 & $1.34 \pm 0.56$ & $1.6 \pm 0.68$ & 46.7 \\
Extract & 250 & $3.69 \pm 0.65$ & $3 \pm 0.32$ & 0 \\
Extract & 500 & $1.71 \pm 1.23$ & $1.6 \pm 1.03$ & 46.7 \\
Extract & 1,000 & $1.75 \pm 0.77$ & $1.8 \pm 0.97$ & 40 \\
\hline Values are expressed as mean $\pm \operatorname{SEM}(n=5)$. & & & \\
${ }^{*} p<0.05$, when compared to the control. & & &
\end{tabular}

Table 2. Effect of aqueous ethanol extract of C. esculentus tuber on intestinal transit of charcoal meal (Mean \pm SEM).

\begin{tabular}{|c|c|c|c|c|c|}
\hline Treatment & $\begin{array}{c}\text { Dose } \\
(\mathrm{mg} / \mathrm{kg})\end{array}$ & $\begin{array}{c}\text { Mean total } \\
\text { length of } \\
\text { intestine }(\mathrm{cm})\end{array}$ & $\begin{array}{l}\text { Mean distance } \\
\text { travelled by } \\
\text { charcoal }(\mathrm{cm})\end{array}$ & $\begin{array}{l}\% \text { Intestinal } \\
\text { transit }\end{array}$ & $\begin{array}{l}\% \text { Intestinal } \\
\text { inhibition }\end{array}$ \\
\hline $1 \%$ tragacanth & $0.1 \mathrm{ml}$ & $87.80 \pm 9.88$ & $61.94 \pm 4.94$ & $72.5 \pm 4.78$ & 29.45 \\
\hline Atropine & 0.1 & $100.74 \pm 9.54$ & $46.04 \pm 6.56$ & $46.38 \pm 4.35$ & 54.3 \\
\hline Extract & 250 & $91.50 \pm 3.47^{* * *}$ & $70.32 \pm 4.19^{* * *}$ & $76.89 \pm 2.41 * * *$ & 23.15 \\
\hline Extract & 500 & $96.90 \pm 5.50^{* * *}$ & $67.92 \pm 3.78^{* * *}$ & $70.68 \pm 4.70^{* * *}$ & 29.9 \\
\hline Extract & 1,000 & $105.80 \pm 2.00 * * *$ & $83.62 \pm 4.04 * * *$ & $79.11 \pm 4.0^{* * *}$ & 20.96 \\
\hline
\end{tabular}

\subsection{Effect of the Extract on Castor Oil Induced Diarrhoea}

The mean weight of wet feces showed a non-statistically significant $(p>0.05)$ reduction in the $(1.71 \pm 1.23 \mathrm{~g}, 1.75 \pm 0.77 \mathrm{~g})$ and mean frequency of watery defecation $(1.6 \pm 1.03,1.8 \pm 0.97)$ at extract doses of 500 and $1,000 \mathrm{mg} / \mathrm{kg}$, respectively, when compared to the controls. Percentage inhibition of defecation was $46.7 \%$ and $40 \%$ at 500 and $1,000 \mathrm{mg} / \mathrm{kg}$ doses of the C. esculentus, respectively, while loperamide had $46.7 \%$ relative to the negative control group. The extract at $250 \mathrm{mg} / \mathrm{kg}$ showed no reduction in the mean weight of wet feces, frequency of watery defecation, and percentage inhibition when compared to the negative control (Table 1).

\subsection{Effect of the Extract on Intestinal Transit of Charcoal Meal}

Cyperus esculentus at the three test doses gave a statistically significant $(p<0.001)$ difference in gastrointestinal movement of charcoal meal, $(70.32 \pm 4.19,67.92 \pm 3.78$, and $83.62 \pm 4.04)$ $\mathrm{cm}$, and $\%$ intestinal transit $(76.89 \pm 2.41 \%, 70.68 \pm 4.70 \%$ and $79.11 \pm 4.0 \%)$, respectively compared to the atropine $(0.1 \mathrm{mg} /$ $\mathrm{kg}$ ). At these same doses, $\%$ intestinal transit was non-statistically significant $(p>0.05)$ compared to the negative control. Atropine showed a significant reduction in the gastrointestinal movement of charcoal meal, the lowest percentage intestinal transit and the highest percentage of intestinal inhibition (54\%) of charcoal meal relative to all the extract treated groups of $(23.15 \%, 29.9 \%$, and $20.96 \%$ ), respectively (Table 2).

\section{DISCUSSION}

Quite a number of antidiarrheal agents act by decreasing either the gastrointestinal motility and/or the secretions. The acute toxicity profile of the extract indicates that it is relatively safe with an $\mathrm{LD}_{50}$ above $5,000 \mathrm{mg} / \mathrm{kg}$ although few signs of toxicity such as itching, sedation, and piloerection were observed at high doses above $1,000 \mathrm{mg} / \mathrm{kg}$.

The plant extract exhibited a non-statistically significantly $(p>$ $0.05)$ reduction in the occurrence of watery defecation at 500 and $1,000 \mathrm{mg} / \mathrm{kg}$ doses relative to the controls in castor oil induced diarrhea model. However, percentage inhibition of defecation produced at $500 \mathrm{mg} / \mathrm{kg}$ was the same as that of loperamide and slightly higher than that of $1,000 \mathrm{mg} / \mathrm{kg}$. This showed that the plant extract was able to inhibit diarrhea more effectively at 500 $\mathrm{mg} / \mathrm{kg}$ dose and so the effect can be said to be non-dose dependent.

Castor oil induces diarrhea through the release of ricinoleic acid, its metabolite [12]. Ricinoleic acid causes irritation of gastric intestinal mucosa, promoting subsequent release of prostaglandin which stimulates gastrointestinal motility and electrolyte secretion, reducing electrolyte absorption from the intestine, and colon thereby resulting in diarrhea. [13].

The plant extract at the three doses produced a statistically significant $(p<0.001)$ difference in gastrointestinal motility of charcoal meal and percentage intestinal transit when compared to the standard drug (atropine), whereas it exhibited a non-statistically significant $(p>0.05)$ difference relative to the negative control. Atropine had almost twice the value of the extract treated groups in percentage inhibition of intestinal transit. This indicates that the plant extract does not seem to possess anti-motility activity. This is because decrease in gastrointestinal motility increases the time of stay of gastrointestinal contents in the intestine which could lead to increase in intestinal water and electrolyte absorption [14] Atropine, the standard drug used in comparison, is an anticholinergic agent blocking $M_{1}$ receptors on gastric parietal cells and blocking $M_{3}$ 
receptors on visceral smooth muscles of stomach and intestine ultimately causing relaxation of these muscles [15].

Preliminary qualitative phytochemical evaluation of the aqueous ethanol extract of $C$. esculentus showed the presence of alkaloids, steroids, cardiac glycosides, carbohydrate, and saponins. However, flavonoids, tannins, anthraquinones, and phlobatannins were observed to be absent in this extract. Medicinal plants with antidiarrheal activity were reported to possess phytochemical constituents, such as tannins, flavonoids, alkaloids, and steroids/terpenoids [16] out of which only alkaloids and steroids were present in C. esculentus ethanol extract. The antidiarrheal properties of flavonoids could be as a result of their being able to reduce intestinal motility and hydro electrolytic secretions which are known to be altered in diarrheic conditions [17]. Moreover, according to Khalilur, flavonoids have been reported to inhibit prostaglandin E2 induced intestinal secretion and spasmogens induced contraction and inhibit release of prostaglandins and autocoids in biological assays [18]. Tannin's antidiarrheal effect as stated by Francesco is due to its involvement in the production of a coagulated protein on the mucosal membrane of the gut which offers some degree of protection, which may lead to a decrease in the sensitivity of nerve endings and peristaltic stimulation [19]. Alkaloids have been implicated in antidiarrheal effect with its reported antispasmodic, antimicrobial, and anticholinergic effect $[20,21]$. The absorption of hydro electrolytes in the intestinal lumen may be positively influenced by the presence of steroids [22]. Hence, lack of effective inhibition of gastrointestinal motility activity of this plant tuber can be attributed to the absence of flavonoids and tannins even though it exhibited some degree of anti-secretory activity through the inhibition of defecation in castor oil induced diarrhea test.

\section{CONCLUSION}

The findings have shown that the aqueous ethanol extract of $C$. esculentus tuber seems to possess anti-secretory effect but does not have anti-motility effect. Thus, the plant can be said to possess some antidiarrheal activity which may likely be due to the presence of alkaloids and steroids as its constituents.

\section{ETHICAL APPROVAL}

As per international standard, written approval of the University research ethics committee was obtained.

\section{CONFLICT OF INTEREST}

The authors hereby declare that there is no conflict of interest.

\section{AUTHORS CONTRIBUTIONS}

Author OAS designed the study and supervised the experimental work, while author DTD carried out the study.

\section{FUNDING}

None.

\section{REFERENCES}

1. WHO. Diarrhoeal disease fact sheet. Available via http://www.who. int/mediacentre/factsheets/fs330/en/ (Accessed May 2017).

2. Bahekar SE, Kale RS. Antidiarrheal activity of ethanolic extract of Manihot esculenta crantz leaves in wistar rats. J Ayurveda Integra Med 2015;6(1):35-40.
3. Fawzi Mahomoodally M. Traditional medicines in Africa: an appraisal of ten potent african medicinal plants. Evid-Based Compl Alt Med 2013;2013:1-15; http://dx.doi.org/10.1155/2013/617459

4. Ndubuisi LC. Evaluation of food potentials of tigernut tubers (Cyperus esculentus) and its products (milk, coffee and wine). Dissertation, Department of Home Science, Nutrition and Dietetics, University of Nigeria, Nsukka, 2009.

5. Biradar S, Kangralkar VA, Mandavkar Y, Thakur M, Chougule N. Anti-inflammatory, anti-arthritic, analgesic and anticonvulsant activity of Cyperus essential oils. Intl J Pharm Pharm Sci 2010;2(4):112-5.

6. Ameen A, El Eraky WI, Yassin NAZ. Hepatoprotective and curative effects of Nigella sativa and Cyperus esculentus oily extracts in liver damage. J Egyptian Soc Pharmacol Exp Ther 1999;18(1):33-41.

7. Oloyede GK, Abimbade SF, Nwabueze CC. Antioxidant and toxicity screening of extracts obtained from Cyperus esculentus. Acad Arena 2014;6(1):77-83.

8. Chevallier A. The encyclopedia of medicinal plants. The University of California, Oakland, CA; DK Publishing, London, UK, 1996.

9. Harborne JB. Phytochemical methods: a guide to modern techniques of plant analysis. 3rd edition, Chapman and Hall, London, UK, 1998.

10. Lorke D. A new approach to acute toxicity testing. Arch Toxicol 1983;54(4):275-89.

11. Sharma P, Vidyasagar G, Singh S, Ghule S, Kumar B. Anti-diarrhoeal activity of leaf extract of Celosia Argentea in experimentally induced diarrhoea in rats. J Adv Pharm Technol Res 2010;1(1):41-8.

12. Niemegeers CJE, Awouters F, Janssen PJA. The castor oil test in rats: an in vivo method to evaluate antipropulsive and antisecretory activity of antidiarrheals? Drug Dev Res 1984;4(2):223-7.

13. Mascolo N, Izzo AA, Barbato F, Capasso F, Inhibitors of nitric oxide synthetase prevent castor-oil-induced diarrhoea in the rat. Brit J Pharmacol 1993;108(4):861-4.

14. Mekonnen B, Asrie AB, Wubneh ZB. Antidiarrheal activity of $80 \%$ methanolic leaf extract of Justicia schimperiana. Evid-Based Compl Alt Med 2018;2018:1-8.

15. Sharma HL, Sharma KK. Principles of pharmacology. 2nd edition, Paras Medical Publishers, Hyderabad, 2011.

16. Chitme HR, Chandra R, Kaushik S. Studies on anti-diarrheal activity of Calotropis gigantean R. Br. In experimental animals. J Pharm Pharm Sci 2004;7(1):70-5.

17. Venkatesan N, Vadivu T, Sathiya N, Arokya A, Sundararajan R, Sengodan G, et al. Antidiarrheal potential of Asparagus racemosus wild root extracts in laboratory animals. J Pharm Pharm Sci 2005;8(1):39-45.

18. Rahman MK, Chowdhury MA, Islam MT, Chowdhury MA, Uddin ME, Sumi CD. Evaluation of antidiarrheal activity of methanolic extract of Maranta arundinacea linn. leaves. Adv Pharmacol Sci 2015;2015(2015):1-6.

19. Capasso F, Gaginella TS, Grandolini G, Izzo, AA. Phytotherapy: a quick reference to herbal medicine. Springer Science \& Business Media, New York, NY, 2003.

20. Ghani, A. Introduction to Pharmacognosy. 1st edition, Ahmadu Bello University, Press Ltd. Zaria, Nigeria, pp 187-97, 1990.

21. Nyarko AA, Addy ME. Effects of aqueous extract of Adenia cissampeloides on blood pressure and serum analyte of hypertensive patients. Phytotherapy Res 1990;4(1):25-28.

22. Birru EM, Asrie AB, Adinew GM, Tsegaw A. Antidiarrheal activity of crude methanolic root extract of Idigofera spicata Forssk. (Fabaceae). BMC Complement Altern Med 2016;16(1):272; doi:10.1186/s12906016-1252-4

How to cite this article:

Shorinwa OA, Dambani DT. Antidiarrheal activity of aqueous ethanol extract of Cyperus esculentus tuber in albino rats. J Appl Biol Biotech 2020;8(03):47-50. DOI: 10.7324/ JABB.2020.80309 